\title{
Short communication: Cinnamaldehyde taste preferences of weaned dairy heifers
}

\author{
C. E. Chapman, ${ }^{*}$ R. G. Cabral,† K. M. Aragona, ${ }^{*}$ and P. S. Erickson* ${ }^{*}$ \\ *Department of Biological Sciences, University of New Hampshire, Durham 03824 \\ †Famo Feeds Inc., Freeport, MN 56331
}

\begin{abstract}
Within a dairy enterprise, one major cost is raising young calves. Optimizing the feeding programs of dairy calves is imperative for the sustainability and profitability of dairy operations. Essential oils appear to be natural alternatives to antibiotics and function similarly to ionophores. Supplemental antibiotic ionophores have been very successful in improving feed efficiency and rate of gain in calves, as well as decreasing disease incidences; however, calves may be developing resistance to ionophores and the use of antibiotics in animal feeds has been a major concern for consumers. No current research has examined the value or palatability of supplementing essential oils to dairy heifers. The purpose of this sequential elimination experiment was to evaluate the taste preferences of 6 weaned dairy heifers [approximately $3 \mathrm{mo}$ old; $95 \pm 10.8 \mathrm{~kg}$ of body weight (BW)] provided with 0 (control), 1, 2, 3, or $4 \mathrm{mg} / \mathrm{kg}$ of BW of cinnamaldehyde daily. Heifers had $2 \mathrm{~d}$ of adaptation to the new feeding regimen before the experiment started and were then offered the 5 experimental diets for $5 \mathrm{~d}$. The most preferred diet was removed and the study continued with the 4 remaining diets. The most preferred diets were again eliminated sequentially, so that only 2 diets remained on $\mathrm{d} 13$ and 14 . Each diet was ranked based on the weight of feed refused at the end of each feeding segment. Overall ranking of the 5 treatments were control, $2,1,3$, and $4 \mathrm{mg} / \mathrm{kg}$ of BW of cinnamaldehyde. Results indicated that heifers preferred diets without cinnamaldehyde; however, when only cinnamaldehyde diets remained, dry matter intake was not negatively affected regardless of the concentration of cinnamaldehyde provided.
\end{abstract}

Key words: heifer, essential oil, cinnamaldehyde, taste preference

Received October 30, 2015.

Accepted January 28, 2016.

${ }^{1}$ Corresponding author: peter.erickson@unh.edu

\section{Short Communication}

Essential oils are gaining interest because the use of antibiotics in animal feeds is facing reduced social acceptance due to the appearance of residues and possible development of antibiotic-resistant bacteria that may pose a risk to human health. The use of antibiotic ionophores, such as lasalocid and monensin, has been very successful in reducing energy and protein losses in the rumen by increasing propionate, decreasing ammonia nitrogen concentrations, and improving feed efficiency in livestock productions (Van Nevel and Demeyer, 1998; Calsamiglia et al., 2007; Benchaar et al., 2008). However, researchers have recently investigated feeding essential oils as an alternative way to achieve the same outcomes as antibiotics to improve heifer health status and feed utilization, thereby increasing rate of gain and decreasing the overall cost of heifer rearing (Calsamiglia et al., 2007; Benchaar et al., 2008).

Essential oils have been studied since the beginning of the 20th century and the most important activities of these compounds are antiseptic and antimicrobial (Cowan, 1999; Burt, 2004). They are considered safe for human and animal consumption (generally recognized as safe, GRAS; US FDA, 2004). Cinnamaldehyde $\left(\mathrm{C}_{9} \mathrm{H}_{8} \mathrm{O}\right)$ is a natural chemical compound found in the bark of the cinnamon tree. It is the active component of cinnamon oil (Cinnamonum cassia), accounting for $75 \%$ of its composition (Calsamiglia et al., 2007). It is a phenylpropanoid with antimicrobial activity and has been studied in poultry and feedlot cattle to determine its effects on disease and feed efficiency (Hume et al., 2006; Calsamiglia et al., 2007; Venkitanarayanan et al., 2013). No data currently exist that describe the palatability effects of cinnamaldehyde supplementation on feed intake or performance of dairy heifers. Therefore, the objective of this study was to determine the shortterm taste preference of cinnamaldehyde at 5 doses $(0$, $1,2,3$, or $4 \mathrm{mg} / \mathrm{kg}$ of BW) to weaned dairy heifers exposed to this compound for the first time, using the sequential elimination procedure of Nombekela et al. (1994). The outcome would then determine which doses 
are tolerable for future studies with cinnamaldehyde and dairy heifers.

This experiment was reviewed and approved by the University of New Hampshire Institutional Animal Care and Use Committee (Protocol \#150103). Six Holstein heifers, approximately 3 mo old $(95 \pm 10.8$ $\mathrm{kg}$ of $\mathrm{BW})$ were used to test the preference of control (no cinnamaldehyde), and $1,2,3$, or $4 \mathrm{mg} / \mathrm{kg}$ of BW of cinnamaldehyde ( $\geq 95 \%$; Sigma-Aldrich Corp., St. Louis, MO). The treatments were chosen based on the amounts of monensin fed to control to prevent coccidiosis. The cinnamaldehyde treatment was added to $20 \mathrm{~g}$ of corn meal carrier, and heifers were fed the experimental TMR (Table 1) at $1000 \mathrm{~h}$ daily. Before the experiment started, the heifers were fed a different diet to decrease any potential bias. It consisted of $50 \%$ corn silage, $12.5 \%$ haylage, $18 \%$ protein mix, $17.5 \%$ energy mix, and $2 \%$ vitamin and mineral mix, with $17.3 \%$ CP, $20.5 \%$ starch, $24.1 \%$ ADF, and $40 \%$ NDF. Components of the protein mix, energy mix, and vitamin and mineral mix were the same as used in the experiment (Table 1). During the experiment, forage and concentrate proportions were different from those before the start of the study. Feed was mixed and delivered using a mobile feed cart (Data Ranger; American Calan Inc., Northwood, NH). Treatments were top-dressed and hand-mixed into each individual feed tub. The pen, experiment setup, and animal number reasoning were similar to that described by Nombekela et al. (1994) and Erickson et al. (2004, 2012). In those studies, 6 animals were used to determine taste preferences. During the experiment, heifers were individually housed in 1 of 2 calf hutches (CalfTel, Germantown, WI) measuring 2.7 $\times 2.2 \times 1.9 \mathrm{~m}$ with an attached pen measuring $2.7 \times$ $3.1 \mathrm{~m}$. Each hutch was bedded with kiln-dried sawdust and water was available for ad libitum consumption. A manger measuring $69 \mathrm{~cm}$ wide $\times 395 \mathrm{~cm}$ long $\times 61 \mathrm{~cm}$ high was placed on one side of the pen, adjacent to the water supply. The manger contained 5 containers, each measuring $27 \mathrm{~cm}$ deep $\times 42 \mathrm{~cm}$ wide $\times 47 \mathrm{~cm}$ long. The containers were positioned randomly at each feeding within the manger except that those on each end were left empty. The same amount of feed was added to each container and calculated to provide $10 \%$ orts for every diet. Feed offered and orts were weighed and recorded daily. Each container held an adequate amount of feed to accommodate a heifer consuming feed from only 1 bin. The experimental period lasted from d 1 to 14 . There were 3 experimental periods with 2 heifers being tested simultaneously. Each heifer was housed and fed individually. Heifers had $2 \mathrm{~d}$ of adaptation to the new feeding regimen before the experiment started and were then offered the 5 experimental diets for $5 \mathrm{~d}$. The most preferred diet was removed and the study continued
Table 1. Ingredient composition (DM \%) of the experimental diet

\begin{tabular}{lc}
\hline Item & Value \\
\hline Corn silage & 57.21 \\
Grass haylage & 22.39 \\
Canola meal & 2.61 \\
Soybean meal & 8.26 \\
Distillers grain & 0.87 \\
Urea & 0.21 \\
Soybean hulls & 0.79 \\
Corn meal & 2.56 \\
Molasses & 0.28 \\
Steam-flaked corn & 0.98 \\
Beet pulp & 1.87 \\
Vitamin and mineral mix & 1.99 \\
\hline
\end{tabular}

${ }^{1}$ Contained $19 \%$ Ca, $6 \%$ P, $3.5 \%$ Mg, $1.5 \%$ K, $2 \%$ S, $7.8 \%$ Na, $12.2 \%$ $\mathrm{Cl}, 25 \mathrm{mg} / \mathrm{kg}$ of Se, $0.26 \% \mathrm{Zn}, 0.29 \% \mathrm{Fe}, 0.26 \% \mathrm{Mn}, 1,196 \mathrm{mg} / \mathrm{kg}$ of $\mathrm{Cu}, 15 \mathrm{mg} / \mathrm{kg}$ of I, $55,089 \mathrm{IU} / \mathrm{kg}$ of vitamin A, 22,848 IU $/ \mathrm{kg}$ of vitamin $\mathrm{D}$, and $454 \mathrm{IU} / \mathrm{kg}$ of vitamin $\mathrm{E}$.

with the 4 remaining diets. The most preferred diet was then eliminated sequentially, so that only 2 diets remained on d 13 and 14 . Therefore, at the end of each feeding segment (d 5, 9, 12, 14), the most preferred diet was eliminated sequentially. The empty tubs were placed on either end of the manger. The ranking of the last 2 treatment diets was determined at the end of the study. Therefore, 5 treatments were offered for $5 \mathrm{~d}, 4$ treatments for $4 \mathrm{~d}, 3$ treatments for $3 \mathrm{~d}$, and 2 treatments for $2 \mathrm{~d}$. Treatments were removed to allow the ranking of the first, second, third, and fourth preferred tastes.

Samples of the TMR and orts were collected daily for determination of DMI. Samples were dried in a forced hot-air convection oven at $55^{\circ} \mathrm{C}$ for $48 \mathrm{~h}$ (Binder, Bohemia, NY). Samples of TMR were pooled over the 14-d feeding period. The composited samples were then ground through a 1-mm screen using a Wiley mill (Thomas Scientific; Swedesboro, NJ). Samples were sent to Analab (Fulton, IL) for analysis of ADF (method 973.18), NDF (method 2002.04), CP (method 990.03), starch (enzymatic method using glucose Trinder method), crude fat (method 920.39), ash (method 942.05), $\mathrm{Ca}, \mathrm{P}, \mathrm{Mg}$, and $\mathrm{K}$ (method 98.01), and S (method 923.01) according to AOAC International methods (AOAC International, 1999; Table 2).

Heifers were weighed on a platform scale (A and A Scales LLC, Prospect Park, NJ) before the experiment started to determine the quantity of cinnamaldehyde $(0,1,2,3$, or $4 \mathrm{mg} / \mathrm{kg}$ of BW $)$ per diet.

Taste preferences were analyzed by ranking the consumption of the diets from most to least preferred. Rankings were determined by giving a 1 to the diet the heifer preferred the most (consumed the most DMI during the first 5-d period when all treatments were given) up to a 5 for the diet the heifer preferred the least. The rankings were summed and then divided by 
Table 2. Chemical analysis (\% of DM) of experimental $\operatorname{diet}^{1}$

\begin{tabular}{lrrc}
\hline Item & Period 1 & Period 2 & Period 3 \\
\hline CP & 14.36 & 14.76 & 15.60 \\
ADF & 25.75 & 22.19 & 22.15 \\
NDF & 38.66 & 34.62 & 34.82 \\
NFC & 38.97 & 42.51 & 41.23 \\
Starch & 21.02 & 24.41 & 24.84 \\
Fat & 2.58 & 2.77 & 2.85 \\
Ash & 7.24 & 7.18 & 7.16 \\
Ca & 0.81 & 0.71 & 0.75 \\
P & 0.46 & 0.45 & 0.46 \\
Mg & 0.29 & 0.25 & 0.26 \\
K & 1.56 & 1.40 & 1.39 \\
Cl & 0.45 & 0.40 & 0.40 \\
S & 0.24 & 0.22 & 0.24 \\
Na & 0.20 & 0.16 & 0.18 \\
\hline
\end{tabular}

${ }^{1}$ Each experimental period lasted from d 1 to 14 . Two heifers were tested simultaneously in each of 3 experimental periods.

the number of heifers used. Agreement among heifers was calculated using Kendall's coefficient of concordance (W) and chi-square (Nombekela et al., 1994).

Intakes of DM for the 5 diets during the first feeding segment $(5 \mathrm{~d})$ of the sequential eliminations are presented in Table 3. During this feeding segment, heifers consumed more of the control treatment, followed by the treatments with 1 and $2 \mathrm{mg}$ of cinnamaldehyde/ $\mathrm{kg}$ of BW.

Table 4 shows the overall DMI throughout the entire data collection period $(14 \mathrm{~d})$. Intakes of DM were typical for the size and age of the heifers. The heifers averaged $2.88 \pm 0.48 \mathrm{~kg} / \mathrm{d}$ of DM during the first feeding segment, $3.30 \pm 0.55 \mathrm{~kg} / \mathrm{d}$ of $\mathrm{DM}$ during the second feeding segment, $3.23 \pm 0.40 \mathrm{~kg} / \mathrm{d}$ of $\mathrm{DM}$ during the third feeding segment, and $3.49 \pm 0.48 \mathrm{~kg} / \mathrm{d}$ of $\mathrm{DM}$ during the last feeding segment, indicating that removal of the most preferred diet did not adversely affect mean daily DMI. Although DMI increased throughout the experiment, this could be attributed to heifers getting older and getting used to the treatments. The total and mean number of days during which diets were chosen as first preference by individual heifers during the first 5-d feeding segment are presented in Table 5. The control treatment ranked first on 22 heifer days, followed by the treatments with 1 and $2 \mathrm{mg} / \mathrm{kg} \mathrm{BW}$
Table 3. Intake of DM $(\mathrm{kg})$ by heifers during the first 5 - $\mathrm{d}$ feeding segment

\begin{tabular}{lrrrrr}
\hline & \multicolumn{5}{c}{ Treatment diet $^{1}$} \\
\cline { 2 - 6 } Heifer & \multicolumn{1}{c}{ CON } & \multicolumn{1}{c}{1} & \multicolumn{1}{c}{2} & \multicolumn{1}{c}{3} & \multicolumn{1}{c}{4} \\
\hline 1 & 3.68 & 3.22 & 3.38 & 0.91 & 0.80 \\
2 & 6.31 & 2.60 & 2.59 & 0.53 & 0.11 \\
3 & 8.59 & 2.61 & 0.56 & 1.46 & 0.32 \\
4 & 8.73 & 4.01 & 1.53 & 1.64 & 1.47 \\
5 & 5.05 & 3.06 & 3.31 & 2.96 & 2.95 \\
6 & 2.89 & 2.01 & 4.05 & 2.71 & 2.24 \\
Total $^{2}$ & 35.26 & 17.50 & 15.41 & 10.21 & 7.91 \\
Mean $^{3}$ & 1.18 & 0.58 & 0.51 & 0.34 & 0.26 \\
\hline
\end{tabular}

${ }^{1} \mathrm{CON}=$ control; $1,2,3$, and $4=1,2,3$, and $4 \mathrm{mg}$ of cinnamaldehyde $/$ $\mathrm{kg}$ of $\mathrm{BW}$, respectively.

${ }^{2}$ Total DM consumed by all heifers for each treatment diet during the first $5 \mathrm{~d}$.

${ }^{3}$ Mean quantity of DM consumed for each treatment diet daily by each heifer during the first $5 \mathrm{~d}$.

of cinnamaldehyde (each preferred for 3 heifer days), the treatment with $3 \mathrm{mg} / \mathrm{kg} \mathrm{BW}$ of cinnamaldehyde (preferred for 2 heifer days), and the treatment with 4 $\mathrm{mg} / \mathrm{kg} \mathrm{BW}$ of cinnamaldehyde (preferred for 0 heifer days). When diets were ranked according to consumption, heifers ranked treatments in the following order: control, $1 \mathrm{mg} / \mathrm{kg}, 2 \mathrm{mg} / \mathrm{kg}, 3 \mathrm{mg} / \mathrm{kg}$, and $4 \mathrm{mg} / \mathrm{kg} \mathrm{BW}$ of cinnamaldehyde (Table 3). Kendall's coefficient of concordance $(\mathrm{W}=0.59)$ and $P$-value of 0.012 indicated differences in preference rankings among heifers. However, the overall ranking of the 5 treatment diets were control, $2 \mathrm{mg} / \mathrm{kg}, 1 \mathrm{mg} / \mathrm{kg}, 3 \mathrm{mg} / \mathrm{kg}$, and $4 \mathrm{mg} / \mathrm{kg} \mathrm{BW}$ of cinnamaldehyde (Table 6), because 1 heifer preferred the $1 \mathrm{mg} / \mathrm{kg}$ treatment least overall.

Currently, no studies have been conducted on feeding essential oils to dairy heifers. Essential oils, specifically cinnamaldehyde, have been studied in feedlot cattle (Yang et al., 2010; Vakili et al., 2013) and lactating dairy cows (Tassoul and Shaver, 2009; Tekippe et al., 2013; Wall et al., 2014), and differences in DMI response and performance have been observed. Feedlot cattle were fed supplemental cinnamaldehyde at 3 doses $(400,800$, or $1,600 \mathrm{mg} / \mathrm{d})$ to determine intake, growth performance, carcass characteristics, and blood metabolite differences compared with monensin (330

Table 4. The average DMI $(\mathrm{kg} / \mathrm{d})$ by each heifer for each feeding segment

\begin{tabular}{llcccccc}
\hline & & \multicolumn{7}{c}{ Heifer } \\
\cline { 3 - 8 } Segment & Days of experiment & 1 & 2 & 3 & 4 & 5 & 6 \\
\hline 1 & 1 to 5 & 2.40 & 2.43 & 2.71 & 3.48 & 3.46 & 2.78 \\
2 & 6 to 9 & 2.92 & 2.95 & 2.98 & 3.85 & 4.15 & 2.97 \\
3 & 10 to 12 & 3.09 & 2.94 & 3.25 & 3.54 & 3.83 & 2.74 \\
4 & 13 to 14 & 3.13 & 3.06 & 3.45 & 3.90 & 4.24 & 3.19 \\
Mean & & 2.80 & 2.78 & 3.01 & 3.66 & 3.85 & 2.88 \\
\hline
\end{tabular}


Table 5. The number of days when treatments were chosen as first preference by heifers during the first 5 -d feeding segment

\begin{tabular}{lccccc}
\hline & \multicolumn{5}{c}{ Treatment diet $^{1}$} \\
\cline { 2 - 6 } Heifer & CON & 1 & 2 & 3 & 4 \\
\hline 1 & 2 & 2 & - & 1 & - \\
2 & 4 & 1 & - & - & - \\
3 & 5 & - & - & - & - \\
4 & 5 & - & - & - & - \\
5 & 4 & - & - & - & - \\
6 & 2 & - & 3 & 2 & 0 \\
Days & 22 & 3 & 3 & 0.33 & 0 \\
Mean $^{2}$ & 3.67 & 0.5 & 0.5 & 0
\end{tabular}

${ }^{1} \mathrm{CON}=$ control; $1,2,3$, and $4=1,2,3$, and $4 \mathrm{mg}$ of cinnamaldehyde/ $\mathrm{kg}$ of $\mathrm{BW}$, respectively.

${ }^{2}$ The average number of days a treatment was chosen per heifer.

mg/d; Yang et al., 2010). The authors confirmed that the response to cinnamaldehyde is dose dependent because DMI responded quadratically to cinnamaldehyde supplementation, with $13 \%$ more feed consumed compared with control during the first $28 \mathrm{~d}$ of the study. Vakili et al. (2013) evaluated the effects of thyme and cinnamaldehyde $(5 \mathrm{~g} / \mathrm{d})$ on growth performance, ruminal fermentation, and blood metabolites in feedlot calves fed high-concentrate diets. Those authors found that neither thyme nor cinnamaldehyde affected DMI, ADG, or feed efficiency, which is in contrast to the results of Vakili et al. (2013). They stated that the effects of essential oils on DMI might vary with the source of essential oil, the type of diet, diet interactions, or adaptations of the rumen microbial population to the different essential oils. Body weight, animal growth stage, and fiber content of the diet can also influence DMI (Vakili et al., 2013).

Studies have shown conflicting results concerning DMI, feed efficiency, and milk production when feeding essential oils to lactating dairy cows. Multiparous Holstein cows were fed a mixture of essential oils (Crina;

Table 6. Ranking of treatments over all the feeding segments ${ }^{1}$

\begin{tabular}{llllll}
\hline & \multicolumn{5}{c}{ Treatment diet $^{2}$} \\
\cline { 2 - 6 } Heifer & CON & 1 & 2 & 3 & 4 \\
\hline 1 & 1 & 3 & 2 & 4 & 5 \\
2 & 1 & 2 & 3 & 4 & 5 \\
3 & 1 & 2 & 4 & 3 & 5 \\
4 & 1 & 2 & 4 & 3 & 5 \\
5 & 1 & 3 & 2 & 4 & 5 \\
6 & 2 & 5 & 1 & 3 & 4 \\
Sum & 7 & 17 & 16 & 21 & 29 \\
Mean & 1.17 & 2.83 & 2.67 & 3.50 & 4.83 \\
\hline
\end{tabular}

${ }^{1}$ Rank of the treatment diets is given with $1=$ most preferred and 5 $=$ least preferred.

${ }^{2} \mathrm{CON}=$ control; $1,2,3$, and $4=1,2,3$, and $4 \mathrm{mg}$ of cinnamaldehyde/ $\mathrm{kg}$ of $\mathrm{BW}$, respectively.
DSM Nutritional Products Inc., Parsippany, NJ) targeted for $1.2 \mathrm{~g} / \mathrm{d}$ (Tassoul and Shaver, 2009). The Crina product is a defined and patented blend of natural and natural-identical essential oil compounds that includes thymol, eugenol, vanillin, and limonene on an organic carrier. Results showed no difference between treatments for actual or fat-corrected milk yields; however, feed efficiency ( $\mathrm{kg}$ of milk per $\mathrm{kg}$ of DMI) tended to be greater, on average, for essential oil-supplemented cows (Tassoul and Shaver, 2009). However, Tekippe et al. (2013) conducted 3 experiments to study the effects of an essential oil product, which contained a blend of $17 \%$ cinnamaldehyde and $28 \%$ eugenol (0, control, or $525 \mathrm{mg} / \mathrm{d}$; Xtract 6965, Pancosma SA, Geneva, Switzerland) and observed no effect on DMI between treatments and minimal effects on rumen fermentation. Wall et al. (2014) also studied the effects of Xtract 6965 on the milk production of lactating dairy cows in varying doses $(200,350,400$, or $600 \mathrm{mg} / \mathrm{d})$ for 6 to 8 wk using Holstein multiparous and primiparous dairy cows. They observed that this blend of essential oils was associated with an increase in DMI in both parity groups but an increase in milk production of multiparous cows only with the $350 \mathrm{mg} / \mathrm{d}$ dose, which disagreed with results of Tekippe et al. (2013), who fed the same product and observed no effects on DMI. Wall et al. (2014) concluded that a blend of cinnamaldehyde and eugenol could increase DMI and milk production in lactating dairy cows; however, it appears that the optimal dose might depend on the parity of the animal. It is unclear how essential oils modulate feed intake, but the effect might be attributed partly to the observed apparent improvement in rumen function, increased fiber digestibility, or both, as found by Tekippe et al. (2013).

Although heifers preferred the control treatment, once it was eliminated, DMI was not affected by cinnamaldehyde dose. Because antibiotics are losing favor due to the concern about residues in milk and the development of antibiotic-resistant bacteria that may pose a risk to human health, more research needs to focus on natural alternatives such as essential oils. Investigating their possible influences on feed efficiency and animal productivity, as well as prevention of coccidiosis in dairy heifers, is critical in the evolution of the dairy industry. These data indicate that cinnamaldehyde does affect feed preference when weaned heifers are given a choice. However, calves consumed all treatments readily when fewer choices were available. This makes cinnamaldehyde an ideal candidate for future comparison studies of ionophores. The cost of heifer rearing is expensive and if supplementing with essential oils such as cinnamaldehyde could improve heifer health status and feed utilization, thus increasing rate of gain and future productivity, dairy operations could decrease their overall 
cost of feeding and managing replacement heifers. Future research regarding supplemental essential oils should focus on feed efficiency and disease incidence in dairy heifers.

\section{ACKNOWLEDGMENTS}

The authors thank the George Walker Fund (Boston, MA) and the New Hampshire Agricultural Experiment Station (Durham). This is Scientific Contribution Number 2640. This work was supported by the USDA National Institute of Food and Agriculture (Washington, DC; NC-2042; accession number 1001283). The authors thank the Fairchild Teaching and Research Center (University of New Hampshire) staff for use of the animals and assistance throughout the study.

\section{REFERENCES}

AOAC International. 1999. Official Methods of Analysis. 16th ed. AOAC International, Gaithersburg, MD.

Benchaar, C., S. Calsamiglia, A. V. Chaves, G. R. Fraser, D. Colombatto, T. A. McAllister, and K. A. Beauchemin. 2008. A review of plant-derived essential oils in ruminant nutrition and production. Anim. Feed Sci. Technol. 145:209-228.

Burt, D. 2004. Essential oils: Their antibacterial properties and potential applications in food-A review. Int. J. Food Microbiol. 94:223-253.

Calsamiglia, S., M. Busquet, P. W. Cardozo, L. Castillejos, and A. Ferret. 2007. Essential oils as modifiers of rumen microbial fermentation: A review. J. Dairy Sci. 90:2580-2595.

Cowan, M. M. 1999. Plant products as antimicrobial agents. Clin. Microbiol. Rev. 12:564-582.

Erickson, P. S., M. L. Davis, C. S. Murdock, K. E. Pastir, M. R. Murphy, C. G. Schwab, and J. I. Marden. 2004. Ionophore taste preferences of dairy heifers. J. Anim. Sci. 82:3314-3320.
Erickson, P. S., S. P. Marston, M. Gemmel, J. Deming, R. G. Cabral, M. R. Murphy, and J. I. Marden. 2012. Short communication: Kelp taste preferences by dairy heifers. J. Dairy Sci. 95:856-858.

Hume, M. E., S. Clemente-Hernández, and E. O. Oviedo-Rondón. 2006. Effects of feed additives and mixed Eimeria species infection on intestinal microbial ecology of broilers. Poult. Sci. 85:21062111.

Nombekela, S. W., M. R. Murphy, H. W. Gonyou, and J. I. Marden. 1994. Dietary preferences in early lactation cows as affected by primary tastes and some common feed flavors. J. Dairy Sci. 77:23932399.

Tassoul, M. D., and R. D. Shaver. 2009. Effect of a mixture of supplemental dietary plant essential oils on performance of periparturient and early lactation dairy cows. J. Dairy Sci. 92:1734-1740.

Tekippe, J. A., R. Tacoma, A. N. Hristov, C. Lee, J. Oh, K. S. Heyler, T. W. Cassidy, G. A. Varga, and D. Bravo. 2013. Effect of essential oils on ruminal fermentation and lactation performance of dairy cows. J. Dairy Sci. 96:7892-7903.

US FDA (US Food and Drug Administration). 2004. 21CFR184: Direct food substances affirmed as generally recognized as safe. Accessed Feb. 17, 2016. https://www.accessdata.fda.gov/scripts/ cdrh/cfdocs/cfcfr/CFRSearch.cfm?CFRPart=184\&showFR $=1$.

Vakili, A. R., B. Khorrami, M. Danesh Mesgaran, and E. Parand. 2013. The effects of thyme and cinnamon essential oils on performance, rumen fermentation and blood metabolites in Holstein calves consuming high concentrate diet. Asian-australas. J. Anim. Sci. 26:935-944.

Van Nevel, C. J., and D. I. Demeyer. 1998. Manipulation of rumen fermentation. Pages 387-443 in The Rumen Microbial Ecosystem. P. N. Hobson, ed. Elsevier Applied Science, New York, NY.

Venkitanarayanan, K., A. Kollanoor-Johny, M. J. Darre, A. M. Donoghue, and D. J. Donoghue. 2013. Use of plant-derived antimicrobials for improving the safety of poultry products. Poult. Sci. 92:493-501.

Wall, E. H., P. H. Doane, S. S. Donkin, and D. Bravo. 2014. The effects of supplementation with a blend of cinnamaldehyde and eugenol on feed intake and milk production of dairy cows. J. Dairy Sci. 97:5709-5717.

Yang, W. Z., B. N. Ametaj, C. Benchaar, M. L. He, and K. A. Beauchemin. 2010. Cinnamaldehyde in feedlot cattle diets: Intake, growth performance, carcass characteristics, and blood metabolites. J. Anim. Sci. 88:1082-1092. 